\section{Whitened Résumés: Race and Self-Presentation in the Labor Market}

\author{
Sonia K. Kang, ${ }^{1}$ Katherine A. DeCelles, ${ }^{1}$ \\ András Tilcsik, ${ }^{1}$ and Sora Jun ${ }^{2}$
}

Administrative Science Quarterly 1-34

(c) The Author(s) 2016

Reprints and permissions:

sagepub.com/

journalsPermissions.nav

DOI: 10.1177/0001839216639577

asq.sagepub.com

@SAGE

\begin{abstract}
Using interviews, a laboratory experiment, and a résumé audit study, we examine racial minorities' attempts to avoid anticipated discrimination in labor markets by concealing or downplaying racial cues in job applications, a practice known as "résumé whitening." Interviews with racial minority university students reveal that while some minority job seekers reject this practice, others view it as essential and use a variety of whitening techniques. Building on the qualitative findings, we conduct a lab study to examine how racial minority job seekers change their résumés in response to different job postings. Results show that when targeting an employer that presents itself as valuing diversity, minority job applicants engage in relatively little résumé whitening and thus submit more racially transparent résumés. Yet our audit study of how employers respond to whitened and unwhitened résumés shows that organizational diversity statements are not actually associated with reduced discrimination against unwhitened résumés. Taken together, these findings suggest a paradox: minorities may be particularly likely to experience disadvantage when they apply to ostensibly pro-diversity employers. These findings illuminate the role of racial concealment and transparency in modern labor markets and point to an important interplay between the self-presentation of employers and the selfpresentation of job seekers in shaping economic inequality.
\end{abstract}

Keywords: résumé whitening, self-presentation, racial discrimination, racial minorities, diversity statements, labor market inequality, stigma

Employment discrimination is a critical process through which organizations can shape the extent and nature of economic inequality in society (Bielby and Baron, 1986; Pager, Western, and Bonikowski, 2009; Rivera, 2012). Despite the proliferation of equal opportunity and diversity initiatives in organizations (Kalev, Dobbin, and Kelly, 2006; Kaiser et al., 2013), discrimination on the basis of race, in particular, remains pervasive in North American labor markets. Résumé audit studies_field experiments that send matched résumé pairs in

\footnotetext{
1 University of Toronto

2 Stanford University
} 
response to real job postings-consistently show evidence of race-based discrimination. Résumés containing minority racial cues, such as a distinctively African American or Asian name, lead to 30-50 percent fewer callbacks from employers than do otherwise equivalent résumés without such cues (Bertrand and Mullainathan, 2004; Oreopoulos, 2011; Gaddis, 2015). Given the crucial role of hiring in occupational attainment, this form of discrimination substantially contributes to labor market inequalities by blocking racial minorities' access to career opportunities (Pager, 2007).

Though the audit literature demonstrates persistent employment discrimination against racial minorities, it provides little insight into how job seekers adapt to this discrimination. By focusing on the demand side of the labor market, this literature does "not reveal the extent to which [minority] individuals change their behavior to avoid experiencing discrimination" (Blank, Dabady, and Citro, 2004: 112; see Pager and Pedulla, 2015). Thus the nature and consequences of the actions that racial minority job seekers might take in anticipation of discrimination remain incompletely understood.

Previous studies have highlighted minority job seekers' use of informal job referral networks (Smith, 2005) and their attempts to cast a relatively wide net in their job search to reach at least some fraction of non-discriminatory employers (Pager and Pedulla, 2015). But the literature has largely overlooked a distinct and potentially critical action that minorities might take to try to avoid anticipated discrimination: changing how they present themselves-especially in relation to racial cues-when applying for jobs. Five decades ago, Goffman (1963) observed how racial minorities attempt to conceal or downplay their minority status in the labor market and beyond. Popular accounts suggest that, even today, minority job seekers might try to avoid discrimination by omitting or strategically presenting race-related information in their job application materials (Yoshino, 2006; Luo, 2009a; Tahmincioglu, 2009). A 2009 article in the New York Times, for example, pointed to a phenomenon colloquially known as "whitening the résumé," whereby black job seekers concealed or "dialed back" racial cues on their résumés (Luo, 2009b). For instance, the article discussed Yvonne Orr, a black woman searching for work in Chicago, who deliberately removed a position at an African American nonprofit organization from her résumé to increase her chances of getting job interviews. Although such actions have been observed anecdotally, systematic research on the nature and consequences of this phenomenon in contemporary labor markets is practically nonexistent.

We investigate résumé whitening by combining qualitative and experimental approaches. First, we qualitatively explore how and why individuals engage in résumé whitening by conducting in-depth interviews with racial minority university students who are about to enter the job market. The interviews shed light on why minority job seekers engage in résumé whitening at the earliest stages of the job application process before their minority status would become obvious to employers (e.g., at an in-person interview). Second, we build on our qualitative findings by conducting a laboratory experiment to examine how job seekers change their résumés in response to different job postings. Third, we report results from a résumé audit study that explores how employers respond to whitened and unwhitened résumés. These three approaches are complementary. The interviews provide fine-grained qualitative insights into the nature of résumé whitening. The lab experiment, conducted with a distinct sample, 
allows us to observe variation in résumé whitening in a controlled setting. Finally, our audit study provides insight into the labor market consequences of résumé whitening.

\section{RACE, STIGMA, AND SELF-PRESENTATION}

Goffman (1963) noted that racial minority status can be a form of "tribal stigma," a collective stigma based on real or imagined attributes associated with a racial group. This, in turn, leads to "discrimination, through which we effectively, if often unthinkingly, reduce [a person's] life chances" (Goffman, 1963: 5). Goffman, however, emphasized that stigmatized individuals might attempt to mitigate the negative impact of stigma by managing the information they convey about themselves. This basic insight provides a basis for conceptualizing how, through self-presentation, people might attempt to "dodge . . . stigmatizing processes" (Link and Phelan, 2001: 378).

According to Goffman, one form of self-presentation by stigmatized individuals involves attempts at concealing the stigma to "pass" as a member of the dominant, non-stigmatized group. Historians have observed numerous instances of racial passing-from the antebellum era to the twentieth century-but they have focused on light-skinned African Americans and multiracial individuals who could pass as white in virtually all interpersonal interactions (Hobbs, 2014). Although this kind of passing is not an option for most racial minorities, Goffman (1963: 74) noted that there are situations in which temporary passing can be an option even for individuals whose racial minority status would be immediately revealed in an in-person interaction:

... the individual will occasionally be in a position to elect to conceal crucial information about himself. . . . black skinned [individuals] who have never passed publicly may nonetheless find themselves, in writing letters or making telephone calls, projecting an image of self that is [only] subject to later discrediting.

This type of selective, temporary passing may be particularly relevant for the job application process in modern labor markets, as it often involves an initial résumé-screening phase (and sometimes a phone interview), with in-person interviews conducted only at a later stage.

Another way of managing a stigmatized identity is what Goffman (1963) called "covering." When covering, individuals attempt neither to completely conceal a stigmatized characteristic (such as their racial minority status) nor to appear as members of the non-stigmatized majority group. Rather, the goal is to downplay the salience of characteristics that foster stigmatization. Thus "persons who are ready to admit possession of a stigma (in many cases because it is known about or immediately apparent) may nonetheless make a great effort to keep the stigma from looming large" (Goffman, 1963: 103). Covering does not render a disfavored identity invisible, but it makes its most damaging aspects less prominent and thus perhaps signals conformity to the non-stigmatized mainstream (Yoshino, 2006). Covering often involves restricting information about the aspects of one's identity that would be most likely to become a basis for discrimination, and this may be an important "assimilative technique" for racial and ethnic minorities (Goffman, 1963: 103): ". . . the intent behind devices such as change in name . . . is not solely to pass, but also to 
restrict the way in which a known-about attribute obtrudes itself into the center of attention. ..." Thus, in the context of race, covering involves "toning down" rather than hiding one's minority status, perhaps to send reassuring signals of conformity to the white majority.

Though Goffman's classic insights into passing and covering are instructive, little is known about how these behaviors operate in modern labor markets, the conditions and motivations under which they occur, and their consequences for employment outcomes. We explore each of these issues in turn, using interviews, a lab experiment, and a field experiment.

\section{STUDY 1: INTERVIEWS}

In the first phase of our investigation, we explored résumé whitening through interviews, focusing on black and Asian university students who were actively searching for jobs or internships. ${ }^{\mathbf{1}}$ This approach offered several advantages. First, the interviews provided an opportunity for an in-depth exploration of the subjective interpretations that shape résumé whitening, allowing us to identify the issues that were most salient to active job seekers. Second, the focus on job-seeking university students illuminated résumé whitening at the first, critical point of entry into relatively highly paid job tracks-an important mechanism in economic stratification (Rivera, 2012). Third, the focus on black and Asian job seekers was informative because, although these groups experience different challenges in North American labor markets (Zeng and Xie, 2004; Pager and Shepherd, 2008), scholars have documented employment discrimination based on racial cues in résumés against both groups (Bertrand and Mullainathan, 2004; Oreopoulos, 2011; Gaddis, 2015). These two groups are certainly not the only minorities to experience discrimination in the labor market, but by focusing on these two groups, we could gain deeper insight into our research question within a group targeted mostly by negative racial stereotypes (i.e., black job seekers) and a group subject to a more mixed set of stereotypes (i.e., Asian job seekers; Fiske et al., 2002; Lin et al., 2005).

\section{Data Collection}

In 2013, two trained research associates conducted 59 in-depth interviews with 29 black and 30 Asian university students who were actively searching for jobs or internships. Given the racially sensitive nature of the subject, we employed one black and one Asian research associate and matched the race of the interviewer to that of each respondent. Participants were from two large, selective, private universities located in a major North American metropolitan area.

Using electronic mailing lists of campus residence halls, we recruited black and Asian participants (55.9 percent women) for a study of minority job seekers' experiences. Participants were undergraduate students in their junior or senior year (95 percent of the sample) or were enrolled in professional degree

\footnotetext{
1 Following our participants' lead, we use the label "black" rather than "African American," and the label "Asian" rather than "Asian American." Although our respondents occasionally used the terms "African American" and "Asian American," they typically did so to describe organizations rather than themselves or other people (e.g., "African American Students' Association" versus "the employer would know that I am black"). In accordance with standard ASQ style, we do not capitalize the words "black" and "white" but capitalize "Asian" and "Hispanic."
} 
programs (5 percent). Every participant had a recent experience applying for jobs or internships. The sample represented a range of targeted career fields, the most common ones being finance (16.9 percent), science and medicine (13.6 percent), law and government (13.6 percent), consulting (10.2 percent), education (8.5 percent), and information technology (5.1 percent).

Each interview started with a discussion of informed consent, including confidentiality protections, and questions to confirm that the participant fit the study criteria (i.e., being a full-time student at one of the two study sites and having had a recent or ongoing experience with submitting a résumé to apply for jobs or internships). The second and main phase of the interviews followed a semi-structured protocol and was tape-recorded and transcribed verbatim. Finally, the interviewers recorded basic information about each participant's background, program of study, and employment history and aspirations. The interviews typically lasted between 30 and 50 minutes and took place at a time and location chosen by the participant.

To introduce the main phase of each interview, the interviewers explained our interest in the experience of minority job seekers and how they present themselves when applying for jobs. Participants then responded to a set of mostly open-ended questions, which allowed them to focus on issues they deemed important. First, interviewers asked participants about their general thoughts and feelings about any steps that someone might take to make it more or less likely that his or her race is revealed when applying for a job. Next, participants discussed whether they or someone they know had ever taken such steps, and the reasons for (or for not) doing so. Finally, they discussed factors that they might consider when deciding whether to include information on their résumé that could potentially reveal their race.

To allay concerns about interviewer bias, we did not share any prior assumptions about résumé whitening with the interviewers. Of course, it is always possible that interviewers may subtly influence the tone or direction of interviews. Within each of the two racial groups, however, respondents expressed highly divergent opinions about the rationality and acceptability of résumé whitening, so it seems unlikely that interviewers were leading them in a particular direction. Moreover, interview transcripts indicate that the key theme that was most consistent across respondents (i.e., engaging in résumé whitening to a lesser degree when targeting pro-diversity employers) emerged spontaneously in response to broad, open-ended questions.

\section{Data Analysis}

We started our analysis by inductively developing a list of first-order codes for the text of the interview transcripts. As we continued to review the transcripts, we organized our first-order codes into second-order conceptual categories. Finally, we organized these second-order categories into two aggregate theoretical dimensions: (1) different types of résumé whitening techniques that respondents described using; and (2) their reported reasons for choosing to whiten or not whiten their résumés. We resolved discrepancies in coding through discussion.

In addition to these steps, we created a role-ordered matrix (Miles and Huberman, 1994) for organizing the coded segments by racial group. This matrix allowed us to detect convergence and divergence in the emergent 
themes across racial lines. There was a high level of convergence in emergent codes and patterns across racial groups; when describing our findings, we note any significant differences by race that we observed.

\section{Whitening Techniques}

Thirty-six percent of interviewees (31 percent of black respondents and 40 percent of Asian respondents) reported that they personally engaged in résumé whitening. In addition, two-thirds of all interviewees reported knowing others (typically friends or family members) who whitened their job application materials; thus awareness of this phenomenon was common even among those respondents who said that they did not personally engage in it. These proportions did not seem to vary substantially by gender, race, or intended career field. There were, however, clear differences between those who routinely whitened their résumés and those who did not, particularly in their perceptions of the threat of employment discrimination.

In what follows, we present (1) findings about the types of whitening techniques that job seekers reported; (2) their motives for using these techniques; and (3) reasons they provided for not using these techniques. A summary of our inductive coding scheme, as well as additional supportive quotations, appears in table 1.

Job seekers described two main types of self-presentation techniques for whitening their résumés: techniques that involved changing the presentation of their name and techniques that entailed modifying the description of their professional and, especially, extra-professional experiences. Job seekers' focus on these aspects of the résumé is not surprising. Names can be a strong signal of racial minority status and a basis for discrimination (Bertrand and Mullainathan, 2004; Oreopoulos, 2011). Extra-professional experiences (such as volunteer work) can signal both human capital and demographic affiliation and thus play an important role in hiring decisions in many (elite and non-elite) white-collar occupations (Rivera, 2011; Tilcsik, 2011).

Presentation of names. Of the participants who reported personally engaging in résumé whitening, nearly one-half indicated that they had changed the presentation of their first name on their résumé. Among Asian respondents, a frequent change was to adopt a first name that was different from their legal or preferred first name, often primarily for the labor market. Echoing a common theme, a Chinese-American college senior-who has lived in the U.S. since she was a toddler-described switching to a more "American-sounding" name on her résumé when applying for finance jobs. This change was consistent with advice she received from career advisors at her university:

Freshman year in my résumé I put my legal name, which is very Chinese-sounding. And then I went to Career Services, and they told me put my American nickname on it instead. . . It wasn't like "Oh you definitely need to do this." It was just like "Oh this is just a suggestion." I think it's just more relatable if you're more Americansounding.

This interviewee noted a substantial increase in the rate of callbacks from employers after the change: "Before I changed it, I didn't really get any 
Table 1. Thematic Coding Analysis

\begin{tabular}{|c|c|c|}
\hline Second-order categories & First-order codes & Representative quotes* \\
\hline \multicolumn{3}{|r|}{ Whitening techniques } \\
\hline \multirow[t]{2}{*}{ Presentation of name } & Altering first name & $\begin{array}{l}\text { "A friend of mine changed her name from a traditional Chinese name to } \\
\text { a more American-sounding name, like Sarah, when she was applying } \\
\text { for jobs. . . She's using that name primarily when doing job stuff." } \\
\text { (Asian, male; finance) }\end{array}$ \\
\hline & Using additional name & $\begin{array}{l}\text { "On the résumé, I have both my Korean name and my English name, } \\
\text { so it kind of compensates for the foreignness. Makes it less foreign." } \\
\text { (Asian, female; law) }\end{array}$ \\
\hline \multirow[t]{3}{*}{$\begin{array}{l}\text { Presentation of } \\
\text { experience }\end{array}$} & Omitting experience & $\begin{array}{l}\text { "I was involved with the National Society for Black Engineers but then } \\
\text { obviously if a company is looking at my résumé and it has that, they } \\
\text { would automatically know that I am or I could be black." (black, male; } \\
\text { investment banking) }\end{array}$ \\
\hline & $\begin{array}{l}\text { Changing description } \\
\text { of experience }\end{array}$ & $\begin{array}{l}\text { "I'm in student leadership for the [University] Black Christian } \\
\text { Fellowship, and on my résumé instead of putting [University] Black } \\
\text { Christian Fellowship, I actually just write [University] Christian } \\
\text { Fellowship." (black, male; education) }\end{array}$ \\
\hline & $\begin{array}{l}\text { Adding "white" } \\
\text { experience }\end{array}$ & $\begin{array}{l}\text { "We have [mostly white campus social clubs] here so I was thinking } \\
\text { about putting the club that I was in on my résumé. . . . [That signals] } \\
\text { having a strong connection to an organization that's affiliated with } \\
\text { white America." (black, male; management consulting) }\end{array}$ \\
\hline
\end{tabular}

Reasons for and against whitening

\begin{tabular}{|c|c|c|}
\hline \multirow[t]{2}{*}{ Motives } & Foot in the door & $\begin{array}{l}\text { "It always goes through my head that I have not got an interview } \\
\text { because I put on my résumé that I worked for a black organization. } \\
\text {.. Me and a couple of friends, we decided to just not put it, just } \\
\text { give yourself an even playing field." (black, male; finance) }\end{array}$ \\
\hline & Signaling assimilation & $\begin{array}{l}\text { "Ultimately you want to do as much as you can to be familiar, relatable } \\
\text { to [employers]." (Asian, male; finance) }\end{array}$ \\
\hline \multirow[t]{5}{*}{ Deterrents } & $\begin{array}{l}\text { Human capital value } \\
\text { of experience }\end{array}$ & $\begin{array}{l}\text { "I can't take that [experience] off because it's an integral part of my } \\
\text { résumé. I couldn't take that out of my résumé." (black, female; } \\
\text { medicine) }\end{array}$ \\
\hline & Screening employers & $\begin{array}{l}\text { "If blackness put a shadow over all [my résumé] then it probably isn't } \\
\text { the job I want to be in." (black, male; fine arts) }\end{array}$ \\
\hline & $\begin{array}{l}\text { Identity-based } \\
\text { objections }\end{array}$ & $\begin{array}{l}\text { "I have considered [whitening my résumé], except for I feel that my } \\
\text { Japanese and Chinese backgrounds are really valuable to my } \\
\text { identity." (Asian, female; education) }\end{array}$ \\
\hline & Belief in meritocracy & $\begin{array}{l}\text { "If you're smart . . I I think that's what they [i.e., the employers in } \\
\text { which I am interested] want. So in that sense I don't think it's logical } \\
\text { for someone to try to hide their racial characteristic if they're a } \\
\text { minority." (Asian, female; financial services) }\end{array}$ \\
\hline & $\begin{array}{l}\text { Assumption that } \\
\text { the targeted } \\
\text { employer values } \\
\text { diversity }\end{array}$ & $\begin{array}{l}\text { "I think diversity is becoming more and more of a [positive] factor in } \\
\text { selection processes these days because the workplaces [l am } \\
\text { targeting] are becoming more diverse, and employers are putting } \\
\text { much more value in those who [are] culturally and ethnically diverse. } \\
\text { (Asian, male; information technology) }\end{array}$ \\
\hline
\end{tabular}

\footnotetext{
* We report each quoted respondent's race, gender, and targeted industry in parentheses.
}

interviews, but after that I got interviews." The majority of Asian respondents mentioned that this practice was widespread among their Asian friends and was seen as an imperative in some industries. A Korean-American female college student remarked, "A lot of my friends, especially the ones who started 
professional schools like business school or law school recently, they took on like American names just because they're like, 'I just have to for my professional career'."

Several other Asian respondents reported using a "white" or "English" first name but noted that they used this name in addition to their "real" name rather than to replace it. Thus these job seekers simultaneously displayed both first names on their résumé, with one of the two names typically placed in parentheses. A Korean-American college student explained, "My freshman year, when I was applying [to internships], I just put my full name, but now I put my [English] nickname first and then my real name in parentheses."

Though modifying first names was most common among Asian respondents, several black participants also reported altering their first name on their résumé, albeit in different ways. The most common technique that these interviewees reported was to use their middle name, rather than first name, if the former sounded more "white" or "neutral" than the latter.

Presentation of experience. More than two-thirds of participants who reported some form of résumé whitening mentioned changing the presentation of their professional or extra-professional experiences. These changes took three forms: (1) omitting experiences that might signal minority status or might be associated with negative racial stereotypes; (2) altering the description of such activities to make them seem more race-neutral; and (3) emphasizing experiences that signaled whiteness or assimilation into "white culture."

Omitting experience. The omission of experiences that could provide racial cues was particularly common among black respondents. In some cases, these omissions allowed job seekers to pass - that is, to appear white or at least not necessarily black —on their résumé. As one black female college student explained, "I've been involved in a lot of black [campus] groups and even though I've had leadership in them ... [I] would take them off my résumé and you really couldn't tell that I was necessarily a black person."

More frequently, however, participants reported omissions that, rather than allowing them to appear white, made their race less salient by "toning down" racial signals. A black female college senior explained:

When I was looking at education, so like teaching things, to send my résumé out to, I was concerned because I'm very involved in black organizations on campus. So I had like Association of Black Women, Black Students' Association, Black Christian Fellowship. I was a little hesitant about having so many black organizations on my résumé, especially a lot of the activity I have done at school have been targeted toward black children. So I did take off a couple of black organizations. . . . I think to me it was just trying to tone down the blackness, for lack of a better word.

Several respondents emphasized that "toning down" race was particularly important for résumé items that might signal an interest in racial identity politics or "black causes." According to a black college senior with an interest in science, résumé items indicating surface-level (i.e., demographic) diversity could be helpful, but items that employers might see as "racially controversial" were to be avoided: 
I've been told to take some things on a résumé off before because they sound like they don't fit the corporate image. . . . [My résumé] says I'm the president of a black campus group, so I am in some way bringing "diversity" to the front, which is seen according to America as a good thing, like at least PR wise. However, I work with middle school kids twice a week through [a program named after an outspoken black abolitionist], not something I mention in job interviews. Additionally, we teach the kids life skills. In the wake of Trayvon Martin, we had a seminar dealing with authority. And that's something that I was told by a black guy at Goldman Sachs to remove from my résumé because of how controversial it could look. . . I guess it just goes to show you, like, that I very much embraced that idea that, to get ahead, some parts of our race need to be only talked about at certain times. Some parts of my racial identity need to be squashed or held back.

Although the removal of race-related résumé items was most common among black respondents, some Asian participants described similar actions. Several Asian respondents, for example, reported removing involvement in Asian student groups from their résumé and described how they concealed "stereotypically Asian activities." Such omissions affected not only extra-professional activities but work experiences as well. As a female college student of Chinese descent noted, "If I'm applying for a position in the Attorney General's Office, I'm not going to bring up the fact that I worked in Chinatown."

Across racial groups, an important feature of the reported omissions was that they implied the concealment of potentially relevant human capital. A black business school student, for example, concealed his involvement in a nationally recognized professional society for black engineers. Likewise, in many of the above-described examples, college students reported concealing leadership roles in campus groups, even though these experiences represent a critical human capital signal for graduating job seekers. One respondent, a black college senior planning a career in education, even omitted a prestigious scholarship from his résumé:

I also did [a career coaching program for minority students] for a little bit. . . . On my résumé previous to joining the program it listed that I was a Gates Millennium Scholar, but then my coach [at the program] told me not to put that because many employers, they see that and depending on who's looking at your résumé they may see that and say "oh, this is a black kid, he was able to get a scholarship from Bill Gates," and this could hurt, you know, my ability to get a job. And so, I no longer put that I'm a Gates Millennium Scholar on my résumé.

Changing the description of experience. Though omitting activities from the résumé meant concealing some aspects of the applicant's human capital, participants also reported techniques for removing racial cues without completely discarding the associated experiences. A black male college senior with a career interest in medicine noted, "When you're whitewashing your résumé, you can phrase racial activities in ways that are still conducive to you getting a job. . . . [It] is something you can spin any way." Typically, this type of "spinning" involved changing the description of experiences to render them racially neutral. A female college student of Korean descent who had applied for government jobs explained, "For some of my volunteer work, it's been like exclusively with Korean organizations, so like the Korean healthcare whatever or 
Korean community services. And actually sometimes I've noticed I take out the word 'Korean' and just put the generic [organization name] on my résumé."

Respondents explained that these more generic or race-neutral descriptions of activities would seem "more prestigious" or "more official" to employers. For example, an Asian college student described her rationale for using a "generic English name" of an art center on her résumé, rather than the center's official, Chinese name:

I list this art class that I took in Chinatown in New York City. But it seems to me it seems less official or less substantial if people recognize it as like, "Oh, it was just like this person who went in to Chinatown every week to take classes for two hours." I feel like they think it's more official if it's like, I don't know, like an official class, like a white person needing the class or something. So yeah-I wouldn't list it on my résumé [with] the Chinese name for it. I just called it the [abbreviation] Art Center....

Adding "white" experience. Although most reported techniques involved omitting or changing the description of certain experiences, several respondents also mentioned trying to change the "feel" of the résumé by adding "white" or "Americanized" extra-professional experiences and interests. A male college student of Bangladeshi descent, who was born and grew up in the U.S. and had work experience in a federal government agency, explained:

There's the lower, miscellaneous or interest category of a résumé that a lot of people have, a lot of the times that's where you want to kind of Americanize your interests. You don't want to be too multicultural with your interests there. So a lot of people will put, you know, hiking or snowboarding or things that are very common to America or Western culture. ...

A female college student of Chinese descent similarly emphasized the "interests" section of the résumé: "So I kind of want to distinguish myself and not just be the perfect cookie-cutter Asian. ... So in my 'interests' section I say that I'm really into wilderness stuff or like travelling."

\section{Reasons For and Against Résumé Whitening}

Motives for whitening. All respondents who reported using whitening techniques said that they did so to improve their chances of getting a job by avoiding anticipated discrimination. Yet job seekers varied in how they described the process through which their whitening actions could accomplish this outcome. Some participants reported that their goal was to "even the playing field" or to "get their foot in the door" by removing all racial cues in their résumés. Therefore the objective was to pass as white at the résumé-screening stage in an attempt to ensure that their race would not surface until they reached the interview phase of the application process. For others, the primary purpose of whitening was to signal assimilation or conformity to the white majority and therefore to avoid triggering negative stereotypes associated with their racial or ethnic group. 
Foot in the door. Approximately one-third of participants who reported some form of résumé whitening mentioned that one key motivation for doing so was to attempt to conceal their racial minority status during the résuméscreening stage of the job application process. These respondents described whitening techniques as a means to getting their foot in the door. Although employers would almost certainly learn of their racial minority status at the interview stage, these job seekers felt that a résumé that did not reveal their race could help them at least receive an invitation for a job interview. As a black law school student explained:

If I have an African name or if I'm like president of the African American Society or something, if that's on my résumé, they automatically know my ethnicity. And because of that, if I have the same credentials as someone of another race, let's say a white person then they would get a callback over me. So if from the beginning they don't know my race ... then I'm more likely to get a callback.

As a result, this respondent found herself in situations "where I had an interview and they did not know my race and I showed up-they were surprised, but I guess they got over that." Thus some job seekers saw résumé whitening as a way to appear white on paper and thereby level the playing field at the initial stage of the application process.

Signaling assimilation. Over three-quarters of participants who reported résumé whitening noted that an important motivation for doing so was to signal assimilation to the racial majority and prevent their minority status from looming large or "sticking out." These respondents emphasized that, to avoid discrimination, minority job seekers needed to signal an ability to "fit in" with white employers and coworkers. In particular, Asian respondents noted that a primary reason for résumé whitening was to signal their assimilation into "white American" or "Western" culture, while black participants emphasized the need to project an image of a conformist, non-political black employee who is uninterested in racial causes.

Asian respondents who made this argument stressed that their goal was, as one such participant put it, "to fit a more American or Western friendly kind of persona." A female respondent of Korean descent explained that this need to fit in exists because Asians are seen as culturally different from the white majority: "I think they do perceive me as an other despite the fact that my English is perfect. Like, I grew up in America. I am a U.S. citizen. . . . But there is-it's still like very stigmatizing to be Asian." Thus these respondents argued that whitening helps them appear more familiar and relatable to employers. As another Asian respondent explained:

... a lot of people who will be looking at your résumé or will be looking to hire you have an easier time identifying or relating to things that are typically, you know, Western culture or typically white culture as opposed to something that might be completely foreign to them. And so I think that's a huge driving force of, you know, trying to whiten your résumé or whiten the job application, is you want them to be able to relate to you.

This notion of making it easier for employers to relate to the résumé and understand the experiences of the applicant was a common theme among these 
respondents. A college student of Taiwanese descent, aspiring for a job at a think tank, noted:

I do think maybe some people might look at [my résumé] and think it's too unAmerican in a way, it's a bit too foreign. . . You know I've done Asian-American dancing troupe-it's not something I would put on my résumé. . . Taiwanese Cultural Society is something I do because I do like to be involved in the community. But . . . I don't want to be identified as too much Taiwanese. I want them to see me as American first.

As an Asian college senior interested in investment banking summarized, "My last name is Asian. It's pretty much like if you look at my résumé you can tell I'm Asian. So then I guess it's a question of preferring whether I'm a really Asian Asian or whether I'm a whitewashed Asian."

Like Asian respondents, the majority of black participants who described engaging in résumé whitening emphasized that an important reason for doing so was to signal their ability to fit in with white employers and coworkers and therefore to remove racial cues that might trigger negative stereotypes.

Whereas Asian respondents were concerned about being seen as "too Asian" or "un-American," however, black job seekers were concerned that they might be perceived as radical, outspoken people involved in racial identity politics. A black college senior explained:

In the real world I think people ... want to have like an awesome black worker but they want one who they feel like fits within a certain box and like very much will conform and like lay low and just kind of do what's expected of them and they're not necessarily looking for the outspoken like political radical person. ... So I feel like to say that you're part of [or] a member of the minority business and entrepreneur group is a different thing from saying like, "oh, I'm the political action chair of the Black Students Association."

Thus, as this respondent elaborated, a common purpose of résumé whitening is to avoid being seen as a person whose race is "sticking out" too much:

[There are] different things and aspects of our personalities that are really important to us but . . . once you get older, I have a sense that it's okay to, like it's time to compact all of that, pretend to just be a square and like don't really express yourself and just kind of like fit in. I feel like race is just one of the many aspects where you try to just like buff the surface smooth and start over and pretend like there's nothing sticking out.

Consistent with this account, several black respondents reported using whitening techniques to downplay their involvement not necessarily in all "black activities" but primarily those that involve identity politics, race relations, or other "racial causes." As a black college student with an interest in management consulting put it, "Because the companies want to know that you're diverse, they want to be able to fill that quota. They want to be able to put you in a box. ... So it's more about avoiding racial causes . . . than it is like necessarily avoiding [black] activity entirely."

Thus many participants across racial minority groups were concerned about their résumés activating negative stereotypes that could make employers think 
that they would be too different from the dominant cultural white majority to fit in well. Whereas removing all racial markers from the résumé was not an option for some job seekers (for instance, if their last name clearly signaled minority status), applicants felt that it was still possible to influence whether their résumé sent a strong signal of racial affiliation or a muted one that indicated assimilation.

Deterrents to whitening. We found five primary deterrents to résumé whitening: (1) the view that the human capital value of an experience was too great to omit from the résumé; (2) the belief that the presence of minority racial cues on the résumé could screen out discriminatory employers; (3) identitybased moral objections to whitening; (4) a belief in the generally meritocratic nature of labor markets; and (5) the assumption that a particular targeted employer values racial diversity.

Human capital value of experience. Several respondents stressed that whitening their work or volunteer history might require concealing potentially important aspects of their human capital. As a black male college student put it, "I think that [the omission of certain activities] definitely becomes problematic because these are real things that I have done, that I have accomplished." As a result, whitening might lead to a significantly sparser résumé. A black college senior used an example from her own experience to highlight this issue:

[l am in] essentially a black choir, we sing spiritual music for the past four years so it's my main extracurricular on campus or one of my main extracurricular activities along with the [University] African American Students' Association. So in a sense I can't take those off my résumé because if I do then I'm not doing anything else on campus or it doesn't look like l'm doing anything else on campus.

Screening employers. Others noted that the removal of racial cues might deprive them of the opportunity to screen employers - that is, to signal their race up front and avoid having to interact with or eventually work for discriminatory employers. A black male college student explained, "I wouldn't consider whitening my résumé because if they don't accept my racial identity, I don't see how I would fit in that job." Thus, by including racial cues on their résumé, some participants felt they could find a less-biased employer and better fit at their job.

Identity-based objections. Though the accounts above emphasized instrumental deterrents to résumé whitening, others rejected the practice on identity-based moral grounds. According to an Asian male college student, "for people to exclude their racial or their ethnic background or any organization that's affiliated with that, I personally find that to be shameful. Everyone should be proud of whatever background they're coming from." Similarly, a black woman, with plans to enter medical school, emphasized that pride in her racial background was an important factor in rejecting the practice: "You can show that you're proud of your culture and involved with part of your ethnicity or in touch with part of it, and I think that's something you should be proud of." Others argued that whitening by anyone who cares about racial equality is 
downright hypocritical. A participant of Chinese descent, interested in a career in law, explained:

\begin{abstract}
A lot of the work I do is legal work and in particular civil rights work. And so I feel like it's almost hypocritical for me to be like, I want to be advocating for people's rights and helping people gain representation and a voice and at the same time in the same breath be like I'm going to somehow whiten myself and change myself to conform. And so I feel like it's almost slapping myself in the face in what I'm trying to do.
\end{abstract}

Belief in meritocracy. Yet another reason for rejecting whitening is the belief that these techniques make little sense because discrimination against racial minority job applicants is rare in most labor markets. A black college student majoring in economics summarized this position:

I mean in today's society I cannot think of a situation in which it will make that much of a difference. . . . Because I feel like today we've progressed to the extent in which [hiring] is based more on qualifications rather than racial identifiers and then there's few instances where racial identifiers are indicative of whether or not you'll get the job.

This argument reflected a great deal of confidence in the fair and meritocratic nature of the hiring process. Respondents who embraced this argument expressed little anxiety about the threat of discrimination, emphasizing that hiring decisions were mostly based on human capital considerations and had little to do with race.

Assuming that the targeted employer values diversity. The majority of participants reported that the characteristics of the targeted employer were an important factor in deciding whether to engage in résumé whitening. In particular, a critical reason that a job applicant who might otherwise engage in résumé whitening would not do so is his or her perception that the targeted employer highly values diverse employees. A black student with business experience in the retail sector illustrated this point by explaining the conditions under which her résumé would include her experience in a black student organization:

If the employer is known for like trying to employ more people of color and having like a diversity outreach program then I would include it because in that sense they're trying to broaden their employees but if they're not actively trying to reach out to other people of other races then, no, I wouldn't include it.

A Taiwanese-American respondent described a similar approach, noting that she chose not to conceal her minority status when applying to a job at a think tank because-even though she perceived racial discrimination to be pervasive in the industry-this particular employer's job posting "did say that they wanted people from different regions" and created an impression that "the organization's big on getting diversity." Thus employers' messages played a crucial role in decisions about whitening. As an African American informant 
noted, ". . . if a company's description let people know that diversity was appreciated or even looked for, then [you] would make sure to include items that would let an employer know that [you] were diverse." Consistently, when targeting employers that appeared to value diversity, job seekers believed they had less reason to worry about discrimination and reported engaging in little, if any, résumé whitening.

\section{STUDY 2: LABORATORY EXPERIMENT}

Our interviews revealed a variety of whitening techniques but also indicated that not all job seekers engage in résumé whitening and that those who do whiten do not do so all the time. With regard to situational variation, minority job seekers reported engaging in less résumé whitening when applying for jobs at organizations with a pro-diversity image. Related research shows that racial minorities are highly attuned to subtle cues in the language and imagery of materials that employers use to present themselves (e.g., corporate brochures) and rely on such cues when assessing an employer's likely treatment of minorities (Purdie-Vaughns et al., 2008). Combined with our interview results, this suggests that a potentially important situational factor affecting the likelihood of résumé whitening is whether organizational statements and other cues affirm the focal employer's commitment to racial diversity. To examine this possibility-and thus provide insight into the conditions under which résumé whitening is more or less likely-Study 2 experimentally manipulated cues to employers' approach to racial diversity in job postings and measured the resulting effect on job seekers' whitening behaviors.

\section{Participants and Procedure}

To facilitate the experimental manipulation of job postings, we conducted this study in the controlled setting of a laboratory but designed several features of our experiment to preserve a degree of external validity. First, we recruited participants from a population whose members make decisions about résumé items on a regular basis: undergraduate business students, who regularly apply for full-time jobs, part-time positions, and internships. Second, participants used their own résumés to complete a task based on job ads that were very similar to those that they would normally target in their actual job searches. Third, participants were unaware that résumé whitening was the focus of our research.

We recruited participants for a "résumé workshop" lab study described in generic terms. Before coming to the lab, participants were asked to submit a copy of their résumé via e-mail to a research assistant and to indicate the business field in which they were most interested (finance, accounting, marketing, or consulting). No participant was excluded from the experiment or the analyses, except that-given our focus on racial minorities-we did not analyze data collected from white participants. ${ }^{2}$ Our sample included 119 undergraduate business students (41 men and 78 women; 87 East Asian, 18 South Asian, and 14 black participants) who received a payment or course credit for their

\footnotetext{
2 Due to logistical concerns and institutional review board guidelines, it would have been difficult to exclude white participants from participating in the experiment. While at the lab, all participants completed a standard demographic questionnaire to indicate their age, gender, and race; we did not analyze data from those who indicated they were white.
} 
participation. All participants were enrolled at a large North American university, different from the two institutions in which we conducted interviews. On average, participants reported 2.8 years of (full-time, part-time, or internship) work experience. $^{3}$

Once at the lab, participants were given an envelope containing a hard copy of their résumé and a job posting, which advertised a position that matched their selected field. Participants were randomly assigned to one of two conditions. In the treatment condition ( $N=62$ ), the job posting included a statement and an image that presented the employer as an organization that valued diversity; in the control condition ( $N=57$ ), the posting included a more generic image and did not mention diversity. Participants prepared a tailored résumé for the job posting by typing information into a standard résumé template in Microsoft Word on a computer. Participants had unlimited space to include as much as they wished in their tailored résumé.

\section{Materials}

To make the job postings realistic, we drew on information from the websites of employers that regularly recruited from our subject population. To ensure that our results were not idiosyncratic to a single type of employer, we randomly assigned participants to see a job posting from one of two firms: Accenture, a multinational professional services firm, or The Parthenon Group, a strategy and private equity consulting firm. Both firms offer positions of potential interest to the subject population. There were no significant differences between these firms, so we collapse data from them when presenting results.

All job postings included the job title, the company logo, and a detailed description of the position. The postings described an identical set of hiring criteria that reflected the language of typical job ads relevant for the study population (e.g., "strong organizational and analytical skills" and "proven ability to work independently and as a team member" in "a high-performance business"). The position was full-time and based in the area; salary was "to be negotiated."

In the treatment condition, the job posting included the following statement: "Accenture/The Parthenon Group is an Equal Opportunity Employer, and strongly values fairness, diversity, and justice." Consistent with this statement, a small image of a diverse group of four people (two women and two men; two white persons and two racial minorities) appeared next to the company logo. Neither this statement nor this picture appeared in the control condition, which featured instead a standard image of a jigsaw puzzle with a pencil on top and simply noted that the employer "values high performance and efficiency," a

\footnotetext{
${ }^{3}$ Although this sample was drawn from a relevant population of job seekers for whom creating a résumé is a natural and realistic task, we acknowledge that the sample-as in most laboratory experiments-is not representative of the broader population. The goal of this experiment, however, was not to draw inferences about the level of résumé whitening broadly but to isolate how an experimentally manipulated factor affects the likelihood of whitening.

${ }^{4}$ A manipulation check confirmed that participants rated the employers as placing greater value on diversity in the treatment condition than in the control condition (significant at the $p<.05$ level). Moreover, the conditions did not differ in the mean rating on the perceived prestige and competitiveness of the job. This indicates that the manipulation successfully and uniquely shaped participants' beliefs about the organization's openness to diversity but did not affect beliefs about other features of the employer or the position.
} 
generic statement similar to the phrases that we used in the non-manipulated parts of the job postings. ${ }^{4}$

To ensure engagement in the task, we matched job advertisements to participants' indicated area of interest. Those who indicated an interest in finance or accounting saw a job advertisement for a Client Financial Management Analyst position; those who indicated an interest in marketing saw an advertisement for a Marketing Analyst role; and those who indicated an interest in consulting saw an advertisement for a Consulting Development Program Business Analyst. Aside from the job title, a few bullet points related to the specific area of interest, and our treatment versus control manipulation, the advertisements were identical in every way. Our results did not vary across the different job titles.

\section{Results}

The primary goal of this experiment was to test whether minority job seekers react to employers' pro-diversity signals by constructing more racially transparent (i.e., less whitened) résumés. Therefore we examined how the treatment and control conditions differed in the proportion of participants who excluded racial minority indicators that were initially present in their original e-mailed résumés from the tailored résumés they created during the experiment. We constructed a variable to capture this outcome in several steps. First, a research assistant who was blind to the experimental conditions coded the name, education, and experience fields of all original résumés for the presence or absence of racial minority indicators. Then a research assistant blind to the conditions coded the same fields of all résumés created during the experiment. We combined these codes, defining résumé whitening as an instance in which a minority racial cue was present in the original résumé but not in the revised one. This occurred, for instance, when an Asian first name was replaced with an English name or when all indication that an experience was associated with a racial minority group was omitted. ${ }^{\mathbf{5}}$ Finally, we constructed our dependent variable as a binary measure capturing whether a participant engaged in résumé whitening in any résumé field (mean $=.29$, standard deviation $=.46$ ).

Table 2 summarizes our results. It shows that in each of the three résumé fields, the proportion of those who engaged in résumé whitening was about 1.5 to 2 times lower when the employer was presented as an organization that values diversity. It is not surprising that some degree of résumé whitening occurred in both conditions; as our interviews indicate, when purposely tailoring a résumé to a particular position, a non-trivial proportion of minority job seekers consider omitting or altering racial cues on their résumé. What our experiment tested, however, was the hypothesis that minorities would engage in significantly less résumé whitening when targeting a job posting with pro-diversity signals. Consistent with this hypothesis, though nearly 39 percent of participants engaged in some form of race concealment in the control condition, only 21 percent of participants did so in the treatment condition. This difference

\footnotetext{
${ }^{5}$ Very few participants (4 out of 119) included a racial minority indicator in a field in their second résumé that was not present in the original résumé.
} 
Table 2. Differences in Résumé Whitening by Employer Description

\begin{tabular}{lcc}
\hline & $\begin{array}{c}\text { Control: } \\
\text { Generic employer } \\
\text { description (N =57) }\end{array}$ & $\begin{array}{c}\text { Treatment: } \\
\text { Pro-diversity } \\
\text { employer (N =62) }\end{array}$ \\
\hline \% Participants who engaged in résumé whitening, by résumé field: & & \\
$\quad$ Name & 7.0 & 4.8 \\
Education & 19.3 & 11.3 \\
Experience & 15.8 & 8.1 \\
\% Participants who engaged in any résumé whitening & 38.6 & 21.0 \\
\hline
\end{tabular}

was statistically significant ( $z=2.11, p<.05$, two-tailed test of proportions), supporting the hypothesis that pro-diversity signals lead minority job applicants to construct less whitened résumés. ${ }^{6}$

\section{STUDY 3: RÉSUMÉ AUDIT STUDY}

To explore the consequences of résumé whitening in the labor market, we conducted a randomized résumé audit study (Bertrand and Mullainathan, 2004; Correll, Benard, and Paik, 2007; Tilcsik, 2011; Gaddis, 2015). This field experimental method, also known as a correspondence study, involves sending applications from fictitious but realistic job seekers in response to actual job postings. Researchers then examine how randomly assigned résumé content, such as the name or an experience, affects the probability that an applicant is contacted for a job interview. Though an interview callback does not guarantee a job offer, it is an important outcome to examine. The résumé-screening stage of the employee-selection process powerfully shapes individuals' subsequent access to opportunities and can serve as a major barrier to employment for racial minorities (Pager, 2003; Pager, Western, and Bonikowski, 2009). One crucial advantage of the audit method is that it generates data about real employers who believe that they are making real decisions about real applicants. In addition to enhancing external validity, audits offer a greater degree of control and more reliable causal evidence than do observational studies (Pager, 2007).

In this audit study, we sent résumés in response to advertised vacancies in U.S. metropolitan areas using a $2 \times 4$ (race $\times$ degree of whitening) betweensubjects factorial design, with one résumé per employer. ${ }^{7}$ As in our interviews, we focused on black and Asian job seekers. Because the interviews revealed two main types of whitening — changing the first name and modifying the description of experience-the degree of résumé whitening in the audit study

\footnotetext{
$\overline{6}$ One possible concern in interpreting our results is that some participants may have whitened their résumé before initially submitting it to us. This, however, would reduce the proportion of résumés for which whitening could be observed during the experiment and thus work against our finding a significant effect of the experimental conditions on whitening. Further, because participants were randomly assigned to conditions, between-participant differences in possible "pre-experiment" whitening would not account for the observed differences across conditions.

7 Though some audit studies send a pair of résumés to each employer, sending one résumé minimized the time burden on each employer (a major concern of our institutional review board) and reduced the risk of detection (Weichselbaumer, 2015).
} 
was either (a) no whitening, (b) whitened first name, (c) whitened experience, or (d) whitened first name and whitened experience.

\section{Experimental Materials}

Our fictitious applicants were recent college graduates with a degree completion date in May 2015, two months before the launch of the audit study. We developed a baseline résumé using templates provided by undergraduate career services offices. Table 3 summarizes items included in our baseline résumé. These items were identical across all conditions. Because employers might ignore job seekers applying from outside their region, we created a local phone number for each city and used a university located in the focal employer's geographic area. These items were constant across all résumés within a metropolitan region. ${ }^{\mathbf{8}}$ We used a web-based telephone service to create phone numbers with area codes that matched the employers' metropolitan area and set up voicemail boxes to record messages. Using a free e-mail service, we also created an e-mail account for each treatment condition. Résumé audit studies of racial discrimination in the U.S. have not revealed significant gender differences (Bertrand and Mullainathan, 2004; Gaddis, 2015), so we used a male first name across all conditions.

For the black applicant's unwhitened résumé, the name appeared as "Lamar J. Smith." We chose Lamar as the first name because it is distinctively African American but does not send a strong signal of low socioeconomic status (Gaddis, 2015). For the last name, we used Smith because it is a common surname among both whites and blacks in the United States (U.S. Census Bureau, 2014) and therefore does not independently send a strong racial signal. The black applicant's unwhitened résumé also listed involvement in two college organizations whose name contained a racial cue: "Vice President, Aspiring African American Business Leaders, [University], 2013-2015" and "Peer Counsellor, [University] Black Students' Association, 2012-2014." The names

\section{Table 3. Summary of Baseline Résumé Items}

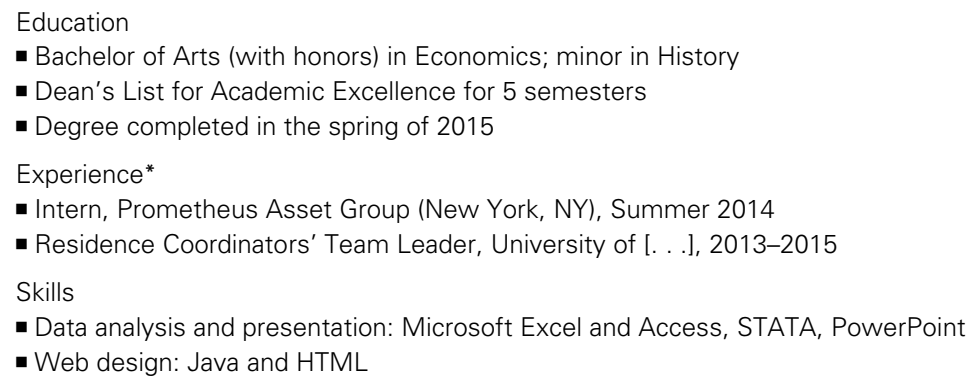

* On the actual résumés, each of these experiences was described in detail with several bullet points, identical across all conditions.

\footnotetext{
${ }^{8}$ For the applicants' undergraduate institution, we selected state universities that were ranked in the 30-80 range in the U.S News ranking of national universities and were located in, or close to, the employer's metropolitan area.
} 
of these activities are similar to those that our interviewees mentioned, and similar organizations are common on college campuses. Like the other experience items on the résumés, each of these activities was described in detail with several bullet points (e.g., "Gathered and coordinated student volunteers for 'Give Kids a Smile' Day" and "Organized and managed first-year student orientation events"). These bullet points did not contain any racial cues and were identical across conditions.

As several black interviewees noted, one whitening technique is to use the middle name rather than the first name if the former is more race-neutral than the latter. Thus, when the black applicant's name was whitened, it appeared as "L. James Smith" rather than "Lamar J. Smith." Also consistent with the interview findings, we whitened the experience section by removing the words "African American" and "Black." Thus "Aspiring African American Business Leaders" became "Aspiring Business Leaders," and "[University] Black Students' Association" became "[University] Students' Association."

On the unwhitened résumé of Asian applicants, the name appeared as "Lei Zhang." We selected this name from a list of common Chinese male given names and surnames that Oreopoulos (2011) used in a recent audit study. The Asian applicant's unwhitened résumé listed the same two college activities as the black applicant's, containing the racial cues "Asian American" and "Asian," respectively.

We whitened the Asian applicant's name from "Lei Zhang" to "Luke Zhang," reflecting the common whitening technique of adopting an English first name. We chose Luke in particular because, like Lei, it is a one-syllable first name that starts with the letter " $L$," and because it is a very common nonHispanic male first name starting with that letter in U.S. cohorts born in the 1990s (i.e., our applicants' cohorts) (U.S. Social Security Administration, 2015).

\section{Procedure}

From July through September 2015, we applied to positions through two of the largest online national job-search websites. ${ }^{\mathbf{9}}$ Our overall sampling frame included entry-level job ads (one per employer) for college graduates, posted in the past 30 days, in 16 geographically dispersed U.S. metropolitan areas. We did not include jobs that required specialized training or certification (e.g., nursing, computer-aided drafting, or advanced foreign language skills). Table 4 shows the distribution of jobs across metropolitan areas, job types, and industries.

Because our interviews and lab experiment suggested that employers' claims of diversity friendliness affected the likelihood of résumé whitening, we implemented a randomized block design that allowed us to examine whether ostensibly diversity-friendly employers did indeed discriminate less than their peers against minorities' unwhitened résumés. To do so, we sampled an equal number of job postings from each metro area with and without explicit prodiversity language, and then we randomly assigned vacancies within each of

\footnotetext{
$\mathbf{9}$ In a recent survey of large firms, companies attributed a quarter of their external hires to jobsearch websites. Nearly 90 percent reported at least one hire in the previous year from one of the two websites used in this study, and more than 80 percent reported at least one hire from the other website we used (Crispin and Mehler, 2011; see Gaddis, 2015). Even as early as 2006, nearly twothirds of surveyed 18 to 28 year olds reported using websites like these for job searches, and that number is likely to have increased since then (Gaddis, 2015).
} 
Table 4. Distribution of Submitted Applications across Metropolitan Areas, Job Types, and Industries in the Résumé Audit Study

\begin{tabular}{|c|c|}
\hline Category & \% Applicatio \\
\hline \multicolumn{2}{|l|}{ Metropolitan areas } \\
\hline \multicolumn{2}{|l|}{ Northeast } \\
\hline Boston & 5.0 \\
\hline New York City & 20.0 \\
\hline \multicolumn{2}{|l|}{ Midwest } \\
\hline Chicago & 5.0 \\
\hline Columbus & 5.0 \\
\hline Minneapolis-Saint Paul & 5.0 \\
\hline \multicolumn{2}{|l|}{ South } \\
\hline Atlanta & 5.0 \\
\hline Charlotte & 5.0 \\
\hline Dallas & 5.0 \\
\hline Houston & 5.0 \\
\hline Nashville & 5.0 \\
\hline Washington & 5.0 \\
\hline \multicolumn{2}{|l|}{ West } \\
\hline Denver & 5.0 \\
\hline Phoenix & 5.0 \\
\hline Los Angeles & 10.0 \\
\hline San Diego & 5.0 \\
\hline San Francisco & 5.0 \\
\hline \multicolumn{2}{|l|}{ Job type } \\
\hline Administrative Assistants and Coordinators & 14.8 \\
\hline Analysts and Consultants & 6.6 \\
\hline Customer Service & 14.9 \\
\hline Human Resources & 9.8 \\
\hline Managerial Trainees & 10.0 \\
\hline Sales and Marketing & 43.8 \\
\hline \multicolumn{2}{|l|}{ Industry (2-digit NAICS codes) } \\
\hline Accommodation and food services & 1.9 \\
\hline Administrative and support, waste management, and remediation services & 13.0 \\
\hline Arts, entertainment, and recreation & 0.5 \\
\hline Construction & 0.6 \\
\hline Educational services & 1.4 \\
\hline Finance and insurance & 13.6 \\
\hline Health care and social assistance & 6.8 \\
\hline Information and cultural industries & 3.0 \\
\hline Management of companies and enterprises & 0.1 \\
\hline Manufacturing & 5.25 \\
\hline Mining, quarrying, and oil and gas extraction & 0.1 \\
\hline Other services (except public administration) & 6.8 \\
\hline Professional, scientific, and technical services & 29.8 \\
\hline Public administration & 0.2 \\
\hline Real estate and rental and leasing & 2.3 \\
\hline Retail trade & 12.1 \\
\hline Transportation and warehousing & 1.8 \\
\hline Utilities & 0.5 \\
\hline Wholesale trade & 0.4 \\
\hline
\end{tabular}


these blocks to one of the eight experimental conditions. To identify ads with an explicit pro-diversity statement, we first searched the text of job postings in each metro area for word roots and variants of the words "diverse" and "inclusive." Then, with the help of a trained research assistant, we manually checked each search result to avoid false positives. For example, while a passage emphasizing that "minorities are strongly encouraged to apply" because the employer "promotes and celebrates diversity and is committed to building a diverse and inclusive workforce" would be coded as containing a pro-diversity cue, a job description focusing on the firm's "diverse portfolio of services" would not be. ${ }^{\mathbf{1 0}}$ Pro-diversity passages typically stated that diversity was a central part of the employer's culture and provided reasons why a diverse workforce was essential to the firm's success (e.g., because it enriched the workplace or helped connect with a diverse customer base). Most of these statements also emphasized a commitment to fairness in hiring and encouraged "diversity candidates" or "underrepresented minorities" to apply.

Given these criteria, we were able to sample 80 job ads (40 with explicit prodiversity language, and 40 without such language) in each metro area, except for Los Angeles and New York City, where we had a larger number of matching postings (160 and 320, respectively). In total, we responded to 1,600 job postings, of which 800 contained explicit pro-diversity language. ${ }^{\mathbf{1 1}}$ We recorded whether each application led to an invitation for an in-person or telephone interview (i.e., a callback). Following common practice in audit studies as well as guidelines of our institutional review board, when an applicant received a callback, we e-mailed the employer to decline the invitation (Correll, Benard, and Paik, 2007; Tilcsik, 2011).

\section{Results}

In total, 267 (or 16.7 percent) of the 1,600 applications led to a job interview request. ${ }^{12}$ Callback rates by condition across all job ads are depicted via the white bars in figure 1 (for black applicants) and figure 2 (for Asian applicants).

\footnotetext{
10 There was little systematic variation in the frequency of pro-diversity statements across industries and job types, except that these statements were less common than average in the construction industry and in the transportation and warehousing industry, and more common than average in the information and cultural industries and the arts, entertainment, and recreation industry. To account for any such variation, as we show below, our results were robust to industry, job type, and location fixed effects. In addition, supplementary analyses (available on request) show that our conclusions were robust to dropping these four industries from the analyses.

11 Each metro area was randomly assigned to a week of the study period. During that week, we identified all job ads in the area that (a) fit the basic sampling criteria and (b) included a pro-diversity statement. We then randomly selected as many of these postings as possible in multiples of 40 and randomly sampled an equal number of postings that fit the sampling criteria but had no prodiversity statement. Thus the total number of sampled job ads in each area was a multiple of 80 . This ensured that the number of observations was equal across the eight experimental conditions within each area and that we had at least ten observations for each condition per area.

$\mathbf{1 2}$ The callback rates were 10.9 percent by e-mail, 4.7 percent by phone, and 1.1 percent by both. Among those who received a callback, there were no significant differences in the mode of contact across conditions. Our overall callback rate was roughly 4 percentage points higher than in Gaddis's (2015) audit with similar baseline résumés. This difference may partly reflect the higher level of job creation during our study period (Bureau of Labor Statistics, 2015); when the supply of positions is relatively high, employers might interview more applicants to compensate for a potentially lower yield.
} 
Figure 1. Callback rates for black applicants.

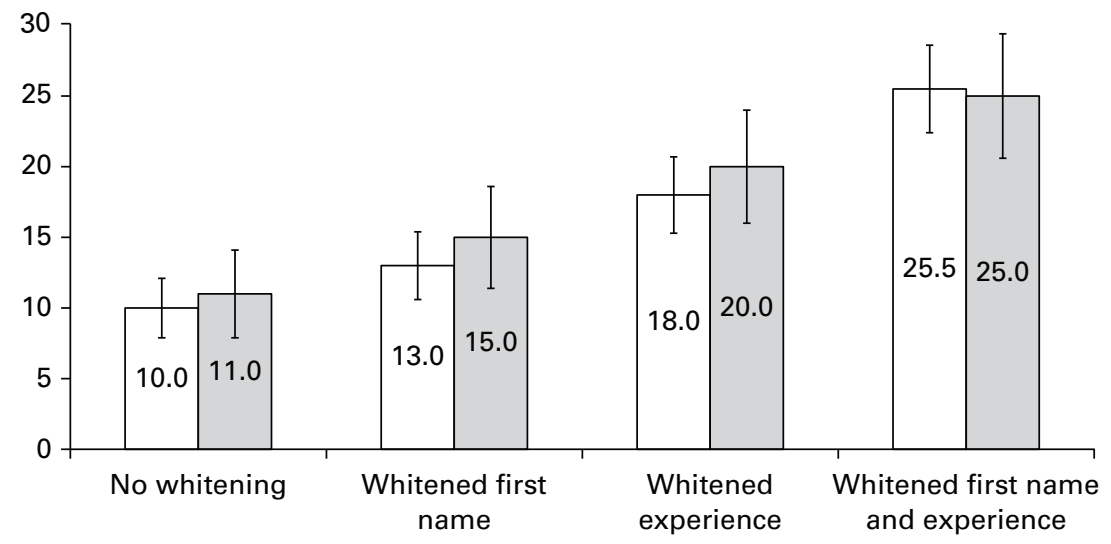

$\square$ All job ads ( $N=200$ in each condition)

$\square$ Subsample of job ads with pro-diversity language ( $N=100$ in each condition)

Figure 2. Callback rates for Asian applicants.

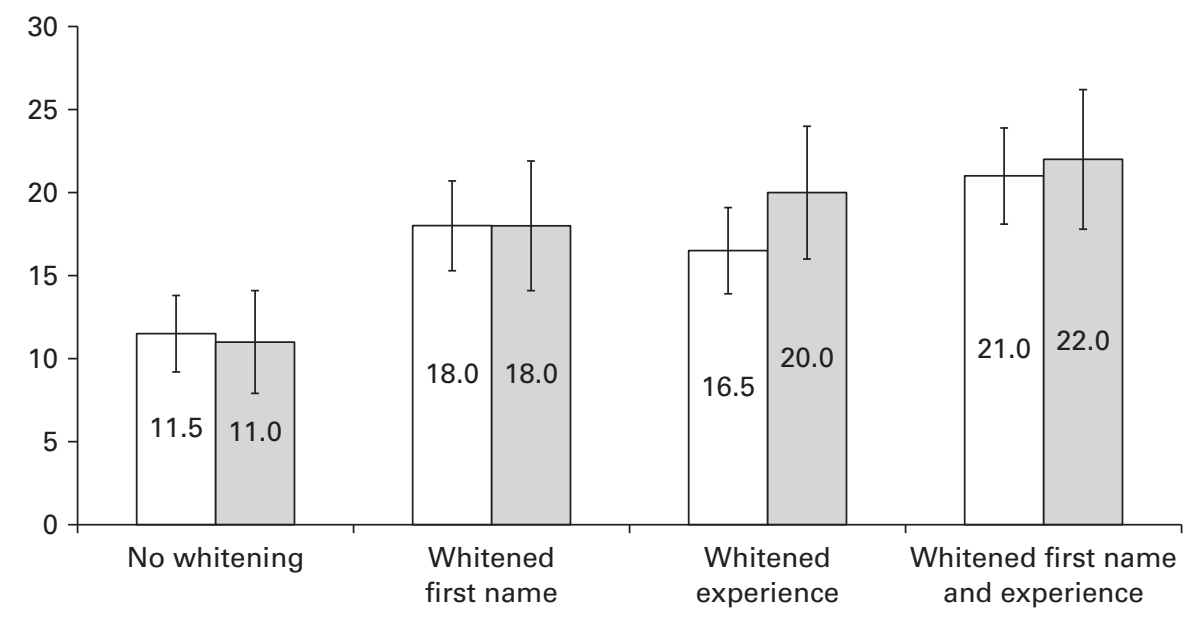

$\square$ All job ads ( $N=200$ in each condition)

$\square$ Subsample of job ads with pro-diversity language ( $N=100$ in each condition)

There is a clear pattern across both groups: whitened résumés led to more callbacks than unwhitened résumés. For blacks, the callback gap between unwhitened résumés and those for which both the name and the experiences were whitened was 15.5 percentage points (a ratio of roughly 2.5 to 1 ). This is a significant difference in proportions $(z=4.06, p<.001)$. For Asians, the callback gap between these conditions was 9.5 percentage points (or a ratio of roughly 1.8 to 1$)$. This gap, too, was statistically significant $(z=2.58, p<.01)$.

With regard to the effect of partial whitening, black applicants who whitened their experiences but not their first name received more callbacks than those 
who did not whiten at all (18 percent versus 10 percent, $z=2.31, p<.05$ ). For Asians, the size of this difference was 5 percentage points but not statistically significant. Whitening the name only (versus not whitening at all) did not make a statistically significant difference for black applicants (13 percent versus 10 percent) but led to a marginally significant increase in callbacks for Asians (18 percent versus 11.5 percent, $z=1.83, p<.10$ ).

Thus figures 1 and 2 reveal just how effective résumé whitening was at closing the callback gap between observably white and non-white applicants. Consider, for example, a job seeker who has a résumé that displays a distinctively African American first name and also lists two "black" extracurricular experiences. Figure 1 suggests that if this person whitened the experience section of his résumé, he would receive about 1.8 times as many callbacks. If he whitened both his first name and the experiences, he would receive 2.5 times as many callbacks as he would with the original, unwhitened résumé. Though the boost from whitening is slightly smaller for Asian job seekers, it is still of a similar order of magnitude as for black applicants. Figure 2, for example, implies that whitening both the first name and the experiences on the résumé could nearly double the callback rate for Asian applicants.

We next examined the subsample of job postings that contained explicit pro-diversity language (see gray bars in figures 1 and 2). Despite the diversity rhetoric, the main patterns in this subsample were similar to those observed across all job ads. As in the full sample, there was a particularly prominent callback gap between unwhitened résumés and those for which both the first name and the experience section were whitened. The size of this gap was 14 percentage points $(z=2.58, p<.01)$ for black applicants (figure 1$)$ and 11 percentage points $(z=2.10, p<.05)$ for Asians (figure 2$)$ - similar to the gap in the full sample.

To provide a more formal test, the linear probability models in table 5 examine whether discrimination against unwhitened résumés was attenuated when the focal job posting contained pro-diversity language. Models 3-5 separately include an interaction between pro-diversity language and each whitening condition; model 6 includes all the interactions. A significant negative coefficient on these interactions would suggest that there was less discrimination against unwhitened résumés (the reference category) when the targeted job posting contained pro-diversity language. In fact, however, most of these coefficients are positive and, without exception, statistically indistinguishable from zero. Thus we do not find evidence that employers using pro-diversity language in their job postings discriminate less against unwhitened résumés.

Further, the linear probability models in table 6 indicate that our main results displayed in figures 1 and 2 were robust to location, job type, and industry fixed effects. As these models show, résumés with whitened first names and experiences led to more callbacks than the unwhitened résumés (the reference category), and this was true for both black and Asian applicants and in both the full sample and the subsample of pro-diversity job postings. ${ }^{13}$

\footnotetext{
$\mathbf{1 3}$ In supplementary models, we explored geographic variation but found few significant and systematic patterns. One exception is that in the Midwest, the callback penalty for unwhitened résumés was somewhat larger than in other regions. Our main results remained robust even when dropping all observations in the Midwest.
} 
Table 5. Testing for Interactions between Pro-diversity Language in Job Ads and the Experimental Conditions: Linear Probability Models Predicting the Likelihood of Callbacks*

\begin{tabular}{|c|c|c|c|c|}
\hline & Model 3 & Model 4 & Model 5 & Model 6 \\
\hline \multicolumn{5}{|l|}{ Conditions (ref.: No whitening) } \\
\hline Whitened first name and experience & $\begin{array}{l}.14^{\bullet \bullet \bullet} \\
(.04)\end{array}$ & $\begin{array}{l}.13^{\bullet \bullet \bullet} \\
(.03)\end{array}$ & $\begin{array}{l}.13^{\bullet \bullet \bullet} \\
(.03)\end{array}$ & $\begin{array}{l}.13^{\bullet \bullet} \\
(.04)\end{array}$ \\
\hline Whitened experience & $\begin{array}{l}.07^{\bullet \bullet} \\
(.02)\end{array}$ & $\begin{array}{c}.04 \\
(.03)\end{array}$ & $\begin{array}{l}.07^{\bullet \bullet} \\
(.02)\end{array}$ & $\begin{array}{c}.04 \\
(.03)\end{array}$ \\
\hline Whitened name & $\begin{array}{l}.05^{\bullet} \\
(.02)\end{array}$ & $\begin{array}{l}.05^{\bullet} \\
(.02)\end{array}$ & $\begin{array}{l}.05 \\
(.03)\end{array}$ & $\begin{array}{c}.04 \\
(.03)\end{array}$ \\
\hline Black (ref.: Asian) & $\begin{array}{c}.00 \\
(.02)\end{array}$ & $\begin{array}{l}.00 \\
(.02)\end{array}$ & $\begin{array}{l}.00 \\
(.02)\end{array}$ & $\begin{array}{l}.00 \\
(.02)\end{array}$ \\
\hline Pro-diversity language (ref.: No diversity language) & $\begin{array}{c}.03 \\
(.02)\end{array}$ & $\begin{array}{l}.01 \\
(.02)\end{array}$ & $\begin{array}{l}.02 \\
(.02)\end{array}$ & $\begin{array}{l}.01 \\
(.03)\end{array}$ \\
\hline \multicolumn{5}{|l|}{ Interaction terms } \\
\hline Whitened first name and experience $\times$ Pro-diversity language & $\begin{array}{r}-.02 \\
(.05)\end{array}$ & & & $\begin{array}{c}.00 \\
(.05)\end{array}$ \\
\hline Whitened experience $\times$ Pro-diversity language & & $\begin{array}{l}.05 \\
(.04)\end{array}$ & & $\begin{array}{l}.05 \\
(.05)\end{array}$ \\
\hline Whitened name $\times$ Pro-diversity language & & & $\begin{array}{l}.00 \\
(.04)\end{array}$ & $\begin{array}{l}.02 \\
(.05)\end{array}$ \\
\hline Constant & $\begin{array}{l}.10^{\bullet \bullet \bullet} \\
(.02)\end{array}$ & $\begin{array}{l}.10^{\bullet \bullet \bullet} \\
(.02)\end{array}$ & $\begin{array}{l}.10^{\bullet \bullet \bullet} \\
(.02)\end{array}$ & $\begin{array}{l}.11^{\bullet \bullet \bullet} \\
(.02)\end{array}$ \\
\hline
\end{tabular}

$\bullet p<.10 ; \bullet p<.05 ; \cdots p<.01$.

${ }^{*}$ Robust standard errors are in parentheses. $N=1,600$.

Table 6. Linear Probability Models with Job Type, Industry, and Metropolitan Area Fixed Effects Predicting the Likelihood of Callbacks*

\begin{tabular}{|c|c|c|c|c|c|c|}
\hline & Model 7 & Model 8 & Model 9 & Model 10 & Model 11 & Model 12 \\
\hline Applicants: & All & Black & Asian & All & Black & Asian \\
\hline Job ads: & All & All & All & Pro-diversity & Pro-diversity & Pro-diversity \\
\hline \multicolumn{7}{|l|}{ Conditions (ref.: No whitening) } \\
\hline Whitened first name and experience & $\begin{array}{l}.12^{\bullet \bullet \bullet} \\
(.03)\end{array}$ & $\begin{array}{l}.14^{\bullet \bullet \bullet} \\
(.04)\end{array}$ & $\begin{array}{l}.09^{\bullet} \\
(.04)\end{array}$ & $\begin{array}{l}.12 \bullet \bullet \\
(.04)\end{array}$ & $\begin{array}{l}.14^{\bullet} \\
(.05)\end{array}$ & $\begin{array}{l}.11^{\bullet} \\
(.05)\end{array}$ \\
\hline Whitened experience & $\begin{array}{l}.07^{\bullet \bullet} \\
(.03)\end{array}$ & $\begin{array}{l}.08^{\bullet} \\
(.04)\end{array}$ & $\begin{array}{c}.07^{\bullet} \\
(.04)\end{array}$ & $\begin{array}{c}.09^{\bullet} \\
(.04)\end{array}$ & $\begin{array}{c}.09 \\
(.05)\end{array}$ & $\begin{array}{l}.11^{\bullet} \\
(.05)\end{array}$ \\
\hline Whitened name & $\begin{array}{l}.06^{\bullet} \\
(.03)\end{array}$ & $\begin{array}{l}.04 \\
(.04)\end{array}$ & $\begin{array}{l}.09^{\bullet} \\
(.04)\end{array}$ & $\begin{array}{c}.06 \\
(.04)\end{array}$ & $\begin{array}{l}.03 \\
(.05)\end{array}$ & $\begin{array}{l}.10 \\
(.06)\end{array}$ \\
\hline Black (ref.: Asian) & $\begin{array}{c}-.01 \\
(.02)\end{array}$ & & & $\begin{array}{c}-.02 \\
(.03)\end{array}$ & & \\
\hline Constant & $\begin{array}{l}.12^{\bullet \bullet} \\
(.04)\end{array}$ & $\begin{array}{l}.11^{\bullet} \\
(.06)\end{array}$ & $\begin{array}{l}.12^{\bullet} \\
(.05)\end{array}$ & $\begin{array}{c}.12^{\bullet} \\
(.06)\end{array}$ & $\begin{array}{c}.12 \\
(.09)\end{array}$ & $\begin{array}{l}.12 \\
(.08)\end{array}$ \\
\hline Observations & 1,600 & 800 & 800 & 800 & 400 & 400 \\
\hline
\end{tabular}

$\bullet p<.05 ; \bullet^{\bullet} p<.01 ; \cdots p<.001$.

* Standard errors are in parentheses. Area, job type, and industry dummies are included in all models, with New York City, Human Resources positions, and the professional, scientific, and technical services industry (NAICS code: 54 ) as the reference categories, respectively. Logit and probit models led to identical conclusions as the models reported here. 
Finally, beyond our primary results, it is worth noting that the difference between our "whitened first name and experience" and "whitened experience" conditions (i.e., the columns on the right-hand side of figures 1 and 2) has been the focus of previous audit studies. For black applicants, this is a comparison of two job seekers who have identical, racially neutral experiences and last names but differ in the racial connotations of their first name-James versus Lamar in this case. The callback gap between these applicants (a ratio of 1.4 to 1 ) is very similar to the gap that Bertrand and Mullainathan (2004) and Gaddis (2015) observed. Likewise, the fact that the gap between Luke Zhang and Lei Zhang-when listing racially neutral experiences-was not significant (21 percent versus 16.5 percent, $z=1.15, p=.25$ ) is in line with findings by Oreopoulos (2011). In addition, the result that the Asian résumé with a whitened first name and experiences led to roughly twice as many callbacks as the unwhitened Asian résumé is also broadly consistent with prior work. Though existing studies have not examined this specific callback gap directly, and little work has examined callback discrimination against Asian job seekers in the United States, research in Canadian labor markets shows that callback rates are approximately three times higher for a résumé with a white name and Canadian education and experience than for an otherwise similar résumé with a Chinese name, education, and experience (Oreopoulos, 2011). Thus while our field experiment extends the audit literature by directly focusing on the effects of résumé whitening, its results are broadly consistent with previous findings.

\section{GENERAL DISCUSSION}

Our multi-method research illuminates the phenomenon of résumé whitening in modern labor markets. We find that while some minority job seekers reject this practice, others view it as necessary and use a variety of techniques to attempt to eliminate explicit racial markers or project an image of a minority applicant who conforms to the perceived expectations of employers. We also find that when targeting an organization that presents itself as valuing diversity, minority applicants engage in significantly less résumé whitening than otherwise, even though our résumé audit study shows that pro-diversity employers' statements are not actually associated with reduced discrimination. These findings suggest implications for understanding self-presentation in labor markets, racial inequality in employment, and stigma management.

\section{Bringing Job Seekers Back In}

Social scientists have focused a great deal of attention on the role of employers in shaping hiring outcomes and patterns of employment discrimination (Bertrand and Mullainathan, 2004; Pager, Western, and Bonikowski, 2009; Oreopoulos, 2011; Rivera, 2012). In contrast, we know less about how job seekers respond to anticipated discrimination. Our study shifts the focus to job seekers, building on the notion that "people in stigmatized groups actively use available resources to resist the stigmatizing tendencies of the more powerful group and ... to the extent that they do, it is inappropriate to portray them as passive recipients of stigma"' (Link and Phelan, 2001: 378). 
We find that the use of techniques for concealing or downplaying one's racial minority status remains a potentially important response to anticipated racial discrimination in employment. Moreover, we find broadly similar responses among black and Asian job seekers, even though members of these minority groups are faced with different challenges and stereotypes in labor markets. Clearly, racial "passing" and "covering" have a long history in North America (Yoshino, 2006; Hobbs, 2014), yet such practices are still very much alive today. Employment outcomes therefore do not simply reflect a one-sided, employer-driven process but, rather, the joint influence of the decisions of employers and the actions of job seekers who attempt to influence employers' decisions through self-presentation.

One important implication is that signals of racial assimilation and conformity may be critical variables in explaining labor market inequalities. Many of our respondents emphasized that what matters in getting a job is not one's racial minority status itself but, rather, the degree to which that status is salient and the type of racial minority that one is perceived to be (e.g., "a really Asian Asian" versus a somewhat "whitewashed" one; or a black worker who "fits within a certain box" versus a potentially outspoken black worker who cares deeply about racial issues). Although these distinctions were salient to a sizable group of job seekers, they are usually excluded from analyses of workplace discrimination and inequality, in which the typical comparison is between a white worker and an otherwise equivalent racial minority worker. What our respondents suggested, however, is that two equally qualified racial minority job seekers might fare very differently in the labor market, depending on how effectively they prevent their race from "sticking out." Capturing such differences in future research will require that we do not measure race in the typical binary fashion but as a continuous or multidimensional construct (Saperstein and Penner, 2012) that taps into the differing degrees to which minority workers signal assimilation to the white majority. Doing so can reveal processes that shape the distribution of labor market opportunities not only between but also within racial groups.

At the same time, though manipulating the display of these signals could help some racial minorities in the labor market, doing so may come at a cost. Projecting an image of a black employee who will "lay low" or an Asian applicant who is deeply assimilated into American culture might imply, as one interviewee put it, having to "squash" certain aspects of one's identity, which may exact a psychological toll (Yoshino, 2006; Pachankis, 2007; Hobbs, 2014). Résumé whitening sometimes also means having to conceal relevant aspects of one's human capital. Doing so may contribute to a self-fulfilling prophecy whereby-in response to being seen by employers as less qualified than white applicants-minority job seekers hide racial markers and thus submit résumés that are indeed sparse in comparison with the résumés of white applicants (Jussim et al., 2000). Whitening, it seems, presents a dilemma rather than a solution.

\section{The Paradox of Diversity Statements}

Our findings suggest that minority job applicants engage in résumé whitening to a lesser degree when targeting organizations that signal a commitment to racial diversity and equality. In this sense, résumé whitening may be as much 
about the self-presentation of employers as it is about the self-presentation of job seekers. In Goffman's (1959) terms, job applicants present themselves to an audience of employers, but at the same time, we show that the applicants themselves are an audience for the self-presentation of employers.

The finding that minority job seekers are more likely to submit racially transparent résumés to ostensibly pro-diversity employers highlights an important paradox, because our audit study suggests that employers that adopt prodiversity statements are in fact just as likely to engage in discrimination against unwhitened résumés as employers that do not display such statements. Thus, paradoxically, given that minority job seekers respond to these statements with greater racial transparency, they may be most likely to experience disadvantage when applying to seemingly diversity-friendly employers. Our audit study suggests that, if an applicant usually whitens his name and experiences on the résumé except when applying to ostensibly pro-diversity employers, then he would receive significantly fewer callbacks from seemingly "diversity-friendly" employers than from those that do not declare their commitment to diversity.

This paradox shares parallels with the "paradox of meritocracy," whereby managers' beliefs that their organization is meritocratic and demography-blind make them more likely to make prejudiced decisions (Castilla and Benard, 2010). The paradox that we point to also arises because of the belief that a particular organization makes employment decisions fairly and on the basis of equal opportunity. In the present case, however, this belief is held not by a firm's managers but by prospective job applicants who, lulled into a false sense of security, may make themselves particularly vulnerable to discrimination.

Why employers that explicitly declare their commitment to diversity still engage in discrimination against minority applicants with unwhitened résumés is a question for future research, but existing studies do suggest relevant insights. Research shows that what employers say about their hiring practices and what they actually do can diverge radically (Pager and Quillian, 2005) and that managers may in fact make more biased evaluation decisions when their company's core values emphasize fairness and meritocracy (Castilla and Benard, 2010). Moreover, there is evidence that many organizational practices aimed at promoting workplace diversity have limited efficacy (Kalev, Dobbin, and Kelly, 2006). In fact, some of the most popular organizational initiatives that are assumed to reduce discrimination actually activate it, while some of the truly effective interventions are rarely used (Dobbin, Schrage, and Kalev, 2015). Thus many organizations that appear (and assume) to be taking steps to promote diversity might achieve limited success in practice. Yet their diversity rhetoric can lead minority job seekers to let their guard down and open themselves up to discrimination.

Discrimination at the résumé screening stage is, of course, just one step in the production of labor market and workplace inequalities (Fernandez and Fernandez-Mateo, 2006; Rivera, 2012). For example, employers' bias at the interview stage and in performance evaluations, pay decisions, and promotions can all have a powerful effect on the opportunity structures and career trajectories of racial minorities (Blank, Dabady, and Citro, 2004; Castilla, 2012). Our study results are also bounded by empirical considerations-they apply to entry-level positions and those in the private sector. Thus investigating the potential effect of racial self-presentation on other employment and workplace processes is an important task for future research. In addition, beyond the 
formal job-seeking channels, many job seekers rely on informal networks and referrals, and scholars have documented various network mechanisms that can isolate minorities from good job opportunities (Smith, 2005; Fernandez and Fernandez-Mateo, 2006). Our study focused on one common avenue for getting a job-applications through formal channels-but the nature of race-related self-presentation may be different when, for example, candidates are referred through social networks. This is an empirical question, and answering it might help refine our conclusions.

\section{Stigma Management}

More broadly, our research advances theories of stigma and stigma management (Paetzold, Dipboye, and Elsbach, 2008). First, though scholars have long noted the use of self-presentational techniques by stigmatized individuals (Goffman, 1963; Link and Phelan, 2001), stigma theory has not fully specified the conditions under which these techniques are more or less likely to be used. One important insight from our research is that the self-presentation of evaluators is key to understanding the self-presentational choices of stigmatized individuals. We show, in particular, that stigmatized individuals' use of passing and covering techniques is contingent on how evaluators present themselves.

Second, we introduce the idea that the selective application of selfpresentation tactics can disadvantage stigmatized individuals. If the audience of evaluators is less accepting than it appears, stigmatized individuals may let their guard down and consequently experience greater disadvantage when interacting with seemingly accepting evaluators. Our research opens the door to examining this paradox in other domains as well. For example, anecdotal evidence suggests that a similar paradox might arise in the case of mental health stigma (Yasgur, 2015) or sexual orientation stigma (McNaron, 1997) in seemingly supportive environments.

Third, we advance stigma theory by highlighting significant variation in the degree to which a stigmatized racial identity is disclosed. Though the importance of the degree of stigma disclosure has been discussed in prior theoretical work (Ragins, 2008), it has mostly been acknowledged with regard to concealable stigmas, such as minority sexual orientation. In contrast, our study shows that the degree of disclosure has implications for economic attainment and inequality even when the stigmatizing mark is visible in face-to-face interactions. Further, while prior work (e.g., Corrigan and Matthews, 2003; Ragins, 2008) has focused on how people disclose their stigma to varying degrees across different life domains (e.g., the workplace versus a non-work domain), we show that individuals disclose their stigma to varying degrees even within a given life domain and that this variation can powerfully shape the distribution of opportunities (e.g., in this case, interview callbacks) in that domain.

Finally, while much research and theorizing have focused on how different evaluators perceive stigmatized individuals (Link and Phelan, 2001; Wiesenfeld, Wurthmann, and Hambrick, 2008), our interviews suggest that stigmatized individuals also vary in the extent to which they experience a given attribute (e.g., their racial minority status) as a stigma. What seems to predict the likelihood of passing and covering behaviors is not simply membership in a stigmatized group but feeling more or less stigmatized. For example, in addition to situational variation, the interviews also pointed to the possibility of stable individual 
differences, as some job seekers never whiten their résumés while others frequently do. Although no major differences emerged along demographic lines, there was a clear pattern in respondents' anticipation of adverse outcomes: those who tended to engage in whitening were highly concerned about the threat of discrimination and employers' negative reactions, and those who never whitened were not. This suggests that perhaps one source of variation in whitening may be individual differences in the tendency to expect and worry about potential adverse consequences in uncertain life domains (Gray and McNaughton, 2000; Hirsh, Mar, and Peterson, 2012). Interestingly, as these concerns may lead stigmatized individuals to be cautious about selfpresentational choices, they may provide a degree of protection from discrimination.

\section{Conclusion}

Racial minorities are well aware of the discrimination that they face in the labor market and selectively disclose their identities in response to the signals that they receive from employers. At the same time, organizations are increasingly recognizing the importance of embracing diversity, and many have adopted explicit pro-diversity statements in an attempt to signal their commitment to reducing labor market inequalities. Adopting such statements does not, however, guarantee any change in discriminatory hiring practices. To the extent that pro-diversity statements encourage job applicants to let their guard down and disclose stigmatized aspects of their identities, these merely cosmetic changes may be doing more harm than good. Future research should continue to examine how the interplay between supply-side and demand-side processes-the self-presentational choices of both job seekers and employers-shape labor market inequality.

\section{Acknowledgments}

This paper has benefited greatly from the comments of numerous colleagues. We are particularly grateful for extremely detailed comments from Roberto Fernandez, Emilio Castilla, and Sameer Srivastava. We also thank Matthew Bidwell, Isabel FernandezMateo, Eunmi Mun, Kim Pernell-Gallagher, and audience members at the 2014 EGOS Symposium, "Sustaining Inequality? The Impact of Organizational Practices on Individual Employment Outcomes."

\section{REFERENCES}

Bertrand, M., and S. Mullainathan 2004 "Are Emily and Greg more employable than Lakisha and Jamal? A field experiment on labor market discrimination." American Economic Review, 94: 991-1013.

Bielby, W. T., and J. N. Baron 1986 "Men and women at work: Sex segregation and statistical discrimination." American Journal of Sociology, 91: 759-799.

Blank, R., M. Dabady, and C. Citro 2004 Measuring Racial Discrimination. Washington, DC: National Academy Press.

Bureau of Labor Statistics 2015 "Employment, hours, and earnings from the current employment statistics survey." http://data.bls.gov/timeseries/CES0000000001?output_view=net_1mth. 
Castilla, E. J.

2012 "Gender, race, and the new (merit-based) employment relationship." Industrial Relations: A Journal of Economy and Society, 51: 528-562.

Castilla, E. J., and S. Benard 2010 "The paradox of meritocracy in organizations." Administrative Science Quarterly, 55: 543-576.

Correll, S., S. Bernard, and I. Paik 2007 "Getting a job: Is there a motherhood penalty?" American Journal of Sociology, 112: 1297-1338.

Corrigan, P., and A. Matthews 2003 "Stigma and disclosure: Implications for coming out of the closet." Journal of Mental Health, 12: 235-248.

Crispin, G., and M. Mehler 2011 "10th annual CareerXroads source of hire report: By the numbers." http:// www.careerxroads.com/news/SourcesOfHire11.pdf.

Dobbin, F., D. Schrage, and A. Kalev 2015 "Rage against the iron cage: The varied effects of bureaucratic personnel reforms on diversity." American Sociological Review, 80: 1014-1044.

Fernandez, R. M., and I. Fernandez-Mateo 2006 "Networks, race, and hiring." American Sociological Review, 71: 42-71.

Fiske, S. T., A. J. Cuddy, P. Glick, and J. Xu 2002 "A model of (often mixed) stereotype content: Competence and warmth respectively follow from perceived status and competition." Journal of Personality and Social Psychology, 82: 878-902.

Gaddis, M. S.

2015 "Discrimination in the credential society: An audit study of race and college selectivity in the labor market." Social Forces, 93: 1451-1479.

Goffman, E. 1959 The Presentation of Self in Everyday Life. Garden City, NY: Doubleday.

\section{Goffman, E.}

1963 Stigma: Notes on the Management of Spoiled Identity. New York: Simon and Schuster.

Gray, J. A., and N. McNaughton 2000 The Neuropsychology of Anxiety: An Enquiry into the Functions of the SeptoHippocampal System. Oxford: Oxford University Press.

Hirsh, J. B., R. A. Mar, and J. B. Peterson 2012 "Psychological entropy: A framework for understanding uncertainty-related anxiety." Psychological Review, 119: 304-320.

Hobbs, A. 2014 A Chosen Exile: A History of Racial Passing in American Life. Cambridge, MA: Harvard University Press.

Jussim, L., P. Palumbo, C. Chatman, S. Madon, and A. Smith 2000 "Stigma and self-fulfilling prophecies." In T. F. Heatherton, R. E. Kleck, M. R. Hebl, and J. G. Hull (eds.), The Social Psychology of Stigma: 374-416. New York: Guilford Press.

Kaiser, C. R., B. Major, I. Jurcevic, T. L. Dover, L. M. Brady, and J. R. Shapiro 2013 "Presumed fair: Ironic effects of organizational diversity structures." Journal of Personality and Social Psychology, 104: 504-519.

Kalev, A., F. Dobbin, and E. Kelly 2006 "Best practices or best guesses? Assessing the efficacy of corporate affirmative action and diversity policies." American Sociological Review, 71: 589-617.

Lin, M. H., V. S. Kwan, A. Cheung, and S. T. Fiske 2005 "Stereotype content model explains prejudice for an envied outgroup: Scale of anti-Asian American stereotypes." Personality and Social Psychology Bulletin, 31: 34-47. 
Link, B. G., and J. C. Phelan

2001 "Conceptualizing stigma." Annual Review of Sociology, 27: 363-385.

Luo, M.

2009a "In job hunt, college degree can't close racial gap." New York Times, November 30. http://www.nytimes.com/2009/12/01/us/01race.html.

Luo, M.

2009b "'Whitening' the resume." New York Times, December 5. http://www .nytimes.com/2009/12/06/weekinreview/06Luo.html.

McNaron, T. A. H.

1997 Poisoned Ivy: Lesbian and Gay Academics Confronting Homophobia. Philadelphia: Temple University Press.

Miles, M. B., and A. M. Huberman

1994 Qualitative Data Analysis. Thousand Oaks, CA: Sage.

Oreopoulos, $\mathrm{P}$.

2011 "Why do skilled immigrants struggle in the labor market? A field experiment with thirteen thousand résumés." American Economic Journal: Public Policy, 3: 148171.

Pachankis, J. E.

2007 "The psychological implications of concealing a stigma: A cognitive-affectivebehavioral model." Psychological Bulletin, 133: 328-345.

Paetzold, R. L., R. L. Dipboye, and K. D. Elsbach

2008 "A new look at stigmatization in and of organizations." Academy of Management Review, 33: 186-193.

Pager, D.

2003 "The mark of a criminal record." American Journal of Sociology, 108: 937-975.

Pager, D.

2007 "The use of field experiments for studies of employment discrimination: Contributions, critiques, and directions for the future." Annals of the American Academy of Political and Social Science, 609: 104-133.

Pager, D., and D. Pedulla

2015 "Race, self-selection, and the job search process." American Journal of Sociology, 120: 1005-1054.

Pager, D., and L. Quillian

2005 "Walking the talk? What employers say versus what they do." American Sociological Review, 70: 355-380.

Pager, D., and H. Shepherd

2008 "The sociology of discrimination: Racial discrimination in employment, housing, credit, and consumer markets." Annual Review of Sociology, 34: 181-209.

Pager, D., B. Western, and B. Bonikowski

2009 "Discrimination in a low-wage labor market: A field experiment." American Sociological Review, 74: 777-799.

Purdie-Vaughns, V., C. M. Steele, P. G. Davies, R. Ditlmann, and J. R. Crosby

2008 "Social identity contingencies: How diversity cues signal threat or safety for African Americans in mainstream institutions." Journal of Personality and Social Psychology, 94: 615-630.

Ragins, B. R.

2008 "Disclosure disconnects: Antecedents and consequences of disclosing invisible stigmas across life domains." Academy of Management Review, 33: 194-215.

Rivera, L. A.

2011 "Ivies, extracurriculars, and exclusion: Elite employers' use of educational credentials." Research in Social Stratification and Mobility, 29: 71-90.

Rivera, L. A.

2012 "Hiring as cultural matching: The case of elite professional service firms."

American Sociological Review, 77: 999-1022. 


\section{Saperstein, A., and A. M. Penner}

2012 "Racial fluidity and inequality in the United States." American Journal of Sociology, 118: 676-727.

Smith, S.

2005 "'Don't put my name on it': Social capital activation and job-finding assistance among the black urban poor." American Journal of Sociology, 111: 1-57.

Tahmincioglu, E.

2009 "Like it or not, name can impact your career: Hiring managers tend to seek out 'mainstream' applicants." http://www.nbcnews.com/id/34063244/ns/businesscareers/t/it-or-not-name-can-impact-your-career.

Tilcsik, A.

2011 "Pride and prejudice: Employment discrimination against openly gay men in the United States." American Journal of Sociology, 117: 586-626.

U.S. Census Bureau

2014 "Frequently occurring surnames from the census 2000." http://www.census .gov/topics/population/genealogy/data/2000_surnames.html.

\section{U.S. Social Security Administration}

2015 "Top names of the 1990s." https://www.ssa.gov/oact/babynames/decades/ names1990s.html.

Weichselbaumer, D.

2015 "Testing for discrimination against lesbians of different marital status: A field experiment." Industrial Relations: A Journal of Economy and Society, 54: 131-161.

Wiesenfeld, B. M., K. A. Wurthmann, and D. C. Hambrick 2008 "The stigmatization and devaluation of elites associated with corporate failures: A process model." Academy of Management Review, 33: 231-251.

Yasgur, B. S.

2015 "Stigmatizing patients with borderline personality disorder." Psychiatry Advisor, April 30. http://www.psychiatryadvisor.com/practice-management/stigmatizingpatients-with-borderline-personality-disorder/article/407316/.

Yoshino, $\mathrm{K}$. 2006 Covering: The Hidden Assault on Our Civil Rights. New York: Random House.

\section{Zeng, Z., and Y. Xie}

2004 "Asian-Americans' earnings disadvantage reexamined: The role of place of education." American Journal of Sociology, 109: 1075-1108.

\section{Authors' Biographies}

Sonia K. Kang is an assistant professor of organizational behavior and human resource management at the Institute for Management and Innovation at the University of Toronto Mississauga. She is cross-appointed to the Rotman School of Management, University of Toronto, 105 St. George Street, Toronto, ON M5S 3E6, Canada (e-mail: sonia.kang@rotman.utoronto.ca). Her research explores stigma, identity, and the challenges and opportunities of diversity. She received her Ph.D. in psychology from the University of Toronto.

Katherine A. DeCelles is an associate professor of organizational behavior and human resource management at the Rotman School of Management, University of Toronto, 105 St. George Street, Toronto, ON M5S 3E6, Canada (e-mail: katy.decelles@rotman .utoronto.ca). Her research focuses on the intersection of organizational behavior and criminology and includes topics such as prison work, inequality, power and selfishness, and activism and aggression. She received her Ph.D. in organizational behavior from the University of Maryland. 
András Tilcsik is an assistant professor of strategic management and a Lee-Chin Institute Fellow at the Rotman School of Management, University of Toronto, 105 St. George Street, Toronto, ON M5S 3E6, Canada (e-mail: andras.tilcsik@rotman utoronto.ca). His research focuses on organizations, occupations, and work. He received his Ph.D. in organizational behavior from Harvard University.

Sora Jun is a Ph.D. candidate in the Graduate School of Business at Stanford University, 655 Knight Way, Stanford, CA 94305 (e-mail: sorajun@stanford.edu). Her research focuses on power and politics, hierarchies, and race and organizations. 